\section{Morphological Plasticity of Dracaena sanderana 'Ribbon' in Response to Four Light Intensities}

\author{
Svoboda V. Vladimirova ${ }^{1}$, Dennis B. McConnell ${ }^{2}$, and Michael E. Kane ${ }^{3}$ \\ Department of Environmental Horticulture, University of Florida, Gainesville, \\ FL 32611 \\ Richard W. Henley ${ }^{2}$ \\ Central Florida Research and Education Center, 2807 Binion Road, Apopka, \\ FL 32703-8504
}

Additional index words. shade level, leaf variegation, growth rate

\begin{abstract}
Effects of four shade levels on the growth of Dracaena sanderana hort Sander ex Mast. 'Ribbon' were evaluated. The experiment was conducted using model structures providing four shade levels $(47 \%, 63 \%, 80 \%$, and $91 \%)$. Dracaena sanderana exhibited morphological plasticity in growth and development. Under $63 \%$ and $80 \%$ shade, plants grew faster and achieved greater biomass than those grown in $47 \%$ and $91 \%$ shade. The lowest $(47 \%)$ and the highest shade $(91 \%)$ provided supraoptimal and suboptimal light levels, respectively. More leaves with less leaf area, larger internodes, and larger root mass developed in plants grown in $63 \%$ shade. Fewer leaves with larger leaf areas, smaller internodes, and smaller root mass developed in plants grown in $80 \%$ shade. Plants grown in $47 \%$ or $63 \%$ shade were less variegated than those grown in $80 \%$ or $91 \%$ shade. Maximum leaf variegation occurred under $91 \%$ shade.
\end{abstract}

Foliage plant production represents an important agricultural industry in the United States with a net wholesale value of $\$ 496$ million in 1994 (U.S. Dept. of Agriculture, 1996). A large part of this industry is devoted to plants with multicolored foliage. Of 135 plant families reported to possess leaf color variegation, the genus Dracaena L. (Agavaceae), represents an economically important group. Commonly grown members of this genus are $D$. fragrans (L.) Ker-Gawl., $D$. deremensis L. Engl., D. marginata Lam., D. surculos $a$ Lindl., and $D$. sanderana hort Sander ex Mast. Popularity of dracaenas can be attributed to their superior performance in interior environments and their diversely colorful foliage (Anderson, 1976), which is enhanced by various leaf variegation patterns. Variegated cultivars of Dracaena are usually most popular; however, varying environmental factors can change variegation from being strongly expressed to barely noticeable. Light intensity influences the amount of variegation in Dracaena sp. (Conover and Poole, 1981). General recommendation for light levels during production of smaller varieties is $280-350$

Received for publication 31 Oct. 1996. Accepted for publication 4 Mar. 1997. Florida Agricultural Experimental Station journal series no. R-05318. Based on part of a thesis accepted in partial fulfillment of the requirements for a MS degree at the Univ. of Florida. We thank R. Stamps and G. Knox for review of the manuscript and instructive criticism. The cost of publishing this paper was defrayed in part by the payment of page charges. Under postal regulations, this paper therefore must be hereby marked advertisement solely to indicate this fact.

${ }^{1}$ Graduate Student.

${ }^{2}$ Professor.

${ }^{3}$ Associate Professor. $\mu \mathrm{mol} \cdot \mathrm{m}^{-2} \cdot \mathrm{s}^{-1}$ (maximum) or $70 \%$ to $80 \%$ shade (Poole et al., 1991). Dracaena sanderana hort. Sander ex Mast. 'Ribbon' (Sander's Dracaena, Belgian Evergreen) belongs to a group of plants referred to as periclinal GWG chimeras (Stewart and Dermen, 1979). The notation GWG relates to the potential for chlorophyll development in the three histogenic shoot meristemlayers: LI-green (G); LII-white(W); and LIII-green (G). Foliage growers have reported that $D$. sanderana 'Ribbon' had increased leaf variegation under shading exceeding $80 \%$. The width of white marginal tissue also decreased as light levels increased (Conover and Poole, 1981). In contrast, two high light-adapted species, Cordyline terminalis (L.) Kunth. (Conover and Poole, 1981) and Codiaemum variegatum (L.) Blume (Carpenter and Nautiyal, 1969), both displayed increased color intensity, as well as increased amount of variegation, under higher light levels. Apparently, differences exist in variegated plant response to light intensity depending on the nature of the variegation and the plant's light intensity optima.

No detailed study on effects of light intensity on the growth and development of $D$. sanderana has been reported to date. This study was undertaken to investigate growth response and amount of variegation of $D$. sanderana 'Ribbon', a variegated shade obligate plant, to four light levels. Measures were taken to minimize other environmental variables under different shade levels.

\section{Materials and Methods}

This investigation was conducted at the Univ. of Florida's Environmental Horticulture Greenhouse complex (Gainesville).
Twenty-four arch-shaped shade structures $(1.85 \times 0.8 \times 0.8 \mathrm{~m}$, length $\times$ width $\times$ height $)$ were located on a gravel bed with their longitudinal axes oriented north-south. The structures consisted of polyvinyl (PVC) pipe frame covered with commercial shade fabric with three shade levels: $47 \%, 63 \%$, and $80 \%$. In addition, $63 \%$ and $80 \%$ shade fabrics were combined to obtain a shade factor of $91 \%$. The lowest shade was selected after preliminary experiments with $D$. sanderana showed light intensities equal to or greater than $70 \%$ of full sun severely reduced growth. Each shade treatment was replicated six times in a completely randomized design. Light intensity and air temperature were monitored in 12 randomly selected structures, with three replicates for each treatment. Light intensity levels were measured using photosynthetically active radiation $(P A R)$ sensors (Sunceram solar cell; Panasonic Co., Trenton, N.J.). Air temperatures were measured using copper-constantan thermocouples (AWG.20). The signals from the thermocouples and the solar cells were recorded hourly by a datalogger (CR-10; Campbell Scientific, Logan, Utah). Relative humidity was monitored using an aspirated wet bulb psychrometer. Details on experimental design and analysis of environmental variables are published elsewhere (Vladimirova et al., 1996).

Data analysis revealed air temperatures under shade were normally above ambient air temperature between 6:00 AM and 6:00 PM. Hourly observations revealed that air temperature differentials fluctuated from ambient by as much as $6^{\circ} \mathrm{C}$. However, when averaged over a 20 - $d$ period, maximum air temperature differentials between shade levels and ambient were 1.2 to $1.9^{\circ} \mathrm{C}$. Although air temperatures under shade exceeded ambient temperature, differences between shade treatments were small. Relative humidity was consistently above $80 \%$ from midnight to 7:00 AM. Plants received irrigation from three sources: natural precipitation, an overhead sprinkler system, and manual watering. The amount of natural precipitation and sprinkler irrigation penetrating the shadecloth was determined with a rain gauge positioned inside the shade structures. The amount of water applied manually was determined separately for each shade level. The base figure for each irrigation period was: natural precipitation plus sprinkler irrigation plus manual irrigation to equal $1 \mathrm{~L}$ per container per application. During the experiment, plants were watered three times a week in July and August and two times a week in September and October.

To ensure lower and more uniform root substrate temperatures, two measures were taken. Plants in 3.1-L (REB Plastics, Orlando, Fla.) containers were double-potted into 6.2-L containers. The space between containers was filled with pea gravel at the bottom and sand on the sides, and two $40 \times 40-\mathrm{cm}$ pieces of burlap and one piece of ground cover with a hole for the plant stem were placed on the top of each container. Substrate temperatures were monitored throughout July and August via handheld soil thermometers inserted $15 \mathrm{~cm}$ below 
the surface in each of the quadrants of the containers at 1:00 PM and 3:00 PM. Double potting and covering the container surface kept maximum substrate temperatures below $32{ }^{\circ} \mathrm{C}$ compared to $45^{\circ} \mathrm{C}$ recorded for container-grown plants in full sun (Ingram, 1981). Based on statistical analysis of monitored environmental parameters under the four shade levels, light intensity, and slight to moderate increases in air and substrate temperatures, were the major factors that influenced $D$. sanderana growth in the shade structures.

The experiment was initiated 7 July 1994. Forty-eight rooted cuttings were transplanted from $10-\mathrm{cm}$ containers into $3.1-\mathrm{L}$ containers containing a commercial potting mix (Metro Mix 500; Grace Sierra, Milpitas, Calif.). The experimental unit consisted of two plants in every shade structure providing six replicates for each shade level. Plants were top-dressed with $5 \mathrm{~g}$ per pot $20 \mathrm{~N}-8.7 \mathrm{P}-16.6 \mathrm{~K}$ slow-release fertilizer (Grace Sierra) at experiment initiation, and every 6 weeks thereafter. The experiment was terminated 31 Oct. 1994. Leaf area measurements were taken with an area meter $(\Delta \mathrm{T}$ Area Meter System; Decagon Devices, Pullman, Wash.). After determining total leaf area, the sensor sensitivity threshold was adjusted to measure only the green area. The amount of variegation was assessed by subtracting the green area from the total leaf area. During the course of the experiment, plantheight was measured biweekly. Other measurements included shoot and root fresh and dry mass, number of roots, number of leaves, stem fresh and dry mass. Final measurements for individual leaves included leaf fresh and dry mass, leaf length and width, total leaf area, and white leaf area. Final measurements included individual internode length and diameter.

Statistical analysis of growth parameters and morphological characteristics was performed using the standard GLM for CRD procedure (SAS Institute, Cary, N.C.).

\section{Results and Discussion}

Dracaena sanderana plants exhibited marked differences when grown under four shade treatments (Table 1, Fig. 1). All monitored growth parameters were significantly affected by shade level. Shoot fresh and dry mass were greatest in plants grown under $80 \%$ shade, while root fresh and dry masses were highest under $63 \%$ shade. Plants grown under 91\% shade had the lowest values for these growth parameters (Table 1). Shoot fresh and dry mass showed a significant quadratic response with increasing shade levels, both curves peaking at $\approx 66 \%$ and $70 \%$ shade for shoot fresh and shoot dry mass, respectively. Root fresh and dry mass response curves were similar to shoot fresh and dry mass curves but peaked at $\approx 59 \%$ and $68 \%$ shade, respectively.

In a study of 10 species, Whitcomb (1979) found different responses of shoot and root mass to light levels ranging from $25 \%$ to $73 \%$ shade, depending on light preferences of the species. Shoot and root mass of sun-requiring plants (Juniperus chinensis L. Lindl., Pyracantha coccinea M.J. Roem, Euonymus japonica Thunb., Elaeagnus macrophylla Thunb.) decreased as shade level increased. Shade-preferring Rhododendron sp. L., Berberis julianae C.K. Scheid., Buxus sempervirens L., Abelia $\times$ grandiflora (Andre) Rehd., and Ilex cornuta Lindl. \& Paxt. had greater shoot and root mass as shade levels were increased to $30 \%$, then shoot and root mass decreased at each increasing shade level. The shade obligate plant in the study, Aucuba japonica Thunb., displayed a different response. As shade levels increased to $63 \%$, shoot and root mass increased. As shade levels increased above $63 \%$, shoot mass increased and root mass decreased. Thus, the results of our work on a shade obligate plant is consistent with Whitcomb's (1979) report.

Dracaena sanderana shoot : root ratio (dry mass) was highest for plants grown under $80 \%$ shade, followed by $91 \%$ shade (Table 1 ). An increase in shoot: root ratio under lower light levels has frequently been reported for "sun" and "shade" plants. The shoot : root ratio of Ficus benjamina L. was higher under $80 \%$ than under 47\% shade (Collard et al., 1977). Rice and Bazzaz (1989) proposed that the decrease in shoot : root ratio under increased light levels may serve as a means of providing an adequate water supply in response to increased transpiration rate. According to Aung (1974), shoot: root ratio decreases under stressful conditions. The increased root development (root fresh mass) under $47 \%$ and $63 \%$ shade in our study suggests that those light levels exceeded the optimum for shoot growth of $D$. sanderana.

Plant height was also affected by light levels (Table 1, Fig. 1). Plants in $80 \%$ shade were tallest, followed by plants in $63 \%, 47 \%$, and $91 \%$ shade. Plant height increased linearly over time (Fig. 2). The slopes of the lines were significantly different and showed two distinct rates of increase; $47 \%$ and $91 \%$ shade in one group and $63 \%$ and $80 \%$ shade in the other. The difference between final plant height within each group was less than $1.8 \mathrm{~cm}$.

Number of leaves per plant varied with shade treatments (Table 1) and exhibited a quadratic response. Plants from $91 \%$ shade had the lowest number of leaves, and plants from $63 \%$ the highest (the difference was six leaves). Leaf number of Leea coccinea Planch. was not affected when plants were grown under shade levels varying from $0 \%$ to $92 \%$ (Sarracino et al., 1992). However, in the same study, leaf number in $L$. rubra Planch. was significantly affected by shade level and fewest leaves developed under $92 \%$ shade. Syngonium podophyllum Scott. had fewer leaves under $80 \%$ than under $47 \%$ shade (Chase and Poole, 1987). In contrast, number of Butia capitata (Mart.) Becc. and Livistona chinensis (Jacq.) R. Br. ex Mart. fronds remained unchanged when plants were grown under $30 \%$, $63 \%$, and $80 \%$ shade (Ingram and McConnell, 1980).

Leaf fresh and dry mass showed a quadratic response (Table 2); however, specific leaf mass was not significantly affected by shading. Leaf length and leaf width also displayed a quadratic response (Table 2) with longest and widest leaves in plants under $80 \%$ shade.

Total leaf area displayed a quadratic response with a peak at $80 \%$ shade (Table 2 ), and lowest values for leaves of plants grown under $47 \%$ and $63 \%$ shade. A similar curvilinear response to increased shade levels for total leaf area was found in $L$. coccinea Planch. (Sarracino et al., 1992); total leaf area increased with each incremental shade increase from $0 \%$ to $63 \%$ but drastically declined under $92 \%$ shade. In contrast, $L$. rubra Planch. developed largest leaf areas under $0 \%$ shade. Leaf areas of the tropical species Theobroma cacao L. and Coffea sp. L. exhibited a linear decrease as shade levels decreased from $85 \%$

Table 1. Growth characteristics of $D$. sanderana plants under four shade levels.

\begin{tabular}{|c|c|c|c|c|c|c|c|}
\hline \multirow[b]{2}{*}{ Observation } & \multicolumn{4}{|c|}{ Shade level (\%) } & \multirow{2}{*}{$\begin{array}{c}\text { Significance } \\
P>\mathrm{F}\end{array}$} & \multirow[b]{2}{*}{ Equation } & \multirow[b]{2}{*}{$R^{2}$} \\
\hline & 47 & 63 & 80 & 91 & & & \\
\hline \multicolumn{8}{|l|}{ Fresh mass (g) } \\
\hline Shoot & $59.9^{2}$ & 65.8 & 66.8 & 46.1 & 0.02 & $y=-6.67 x^{2}+29.33 x+36.45$ & 0.95 \\
\hline Root & 11.6 & 13.1 & 10.9 & 8.4 & 0.01 & $y=-0.97 x^{2}+3.68 x+9.04$ & 0.95 \\
\hline Stem & 30.0 & 31.9 & 31.5 & 19.6 & 0.01 & $y=-3.44 x^{2}+14.06 x+18.89$ & 0.96 \\
\hline \multicolumn{8}{|l|}{ Dry mass (g) } \\
\hline Shoot & 9.0 & 10.9 & 11.4 & 7.9 & 0.05 & $y=-1.34 x^{2}+6.43 x+3.83$ & 0.95 \\
\hline Root & 1.7 & 2.4 & 1.7 & 1.3 & 0.02 & $y=-0.32 x^{2}+1.42 x+0.71$ & 0.65 \\
\hline Stem & 3.6 & 4.5 & 5.4 & 3.0 & 0.01 & $y=-0.82 x^{2}+4.03 x+0.23$ & 0.83 \\
\hline Shoot : root ratio (dry mass) & 5.4 & 4.6 & 6.7 & 5.8 & 0.05 & $y=0.38 x+4.58$ & 0.23 \\
\hline Plant height $(\mathrm{cm})$ & 51.3 & 60.7 & 61.7 & 49.6 & 0.01 & $y=-5.36 x^{2}+26.38 x+30.07$ & 0.99 \\
\hline Leaf number & 28.7 & 29.3 & 26.7 & 23.3 & 0.05 & $y=-x^{2}+3.12 x+26.7$ & 0.99 \\
\hline Root number & 22.7 & 27.1 & 26.7 & 27.2 & 0.05 & $y=-0.98 x^{2}+6.18 x+17.82$ & 0.89 \\
\hline
\end{tabular}

${ }^{\mathrm{z}}$ Means based on a sample of six replicates. 


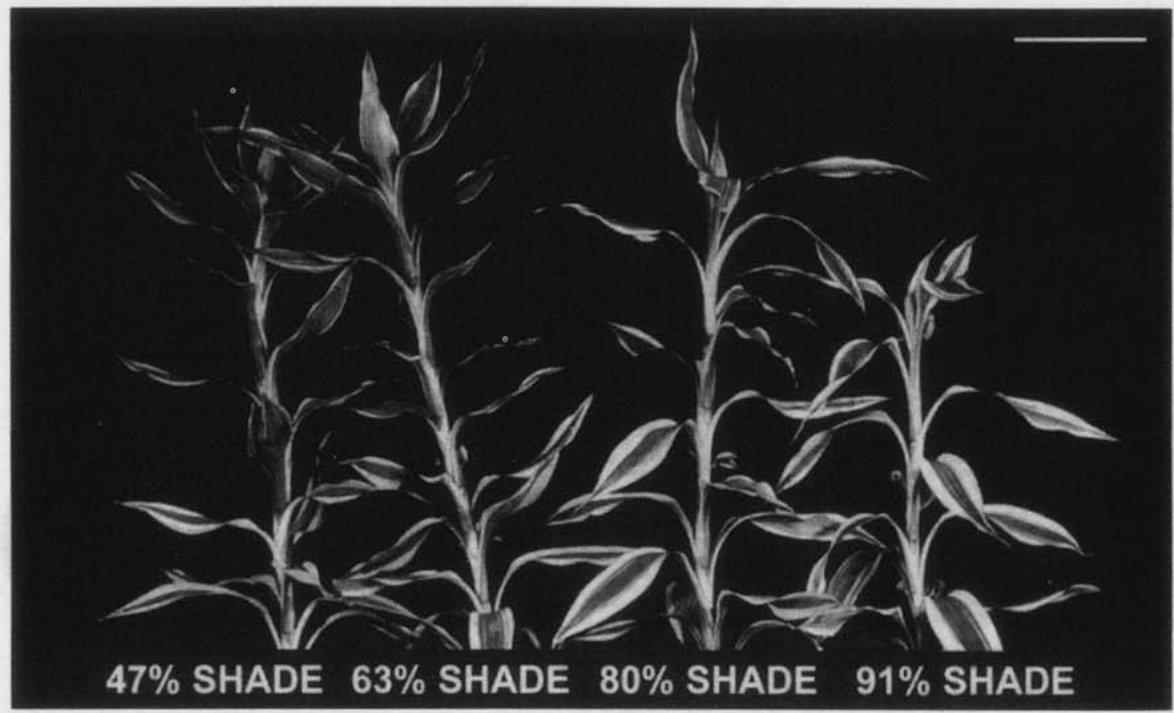

Fig. 1. Representative plants of $D$. sanderana after 15 weeks of growth under $47 \%, 63 \%, 80 \%$, or $91 \%$ shade. $\mathrm{Bar}=5 \mathrm{~cm}$.

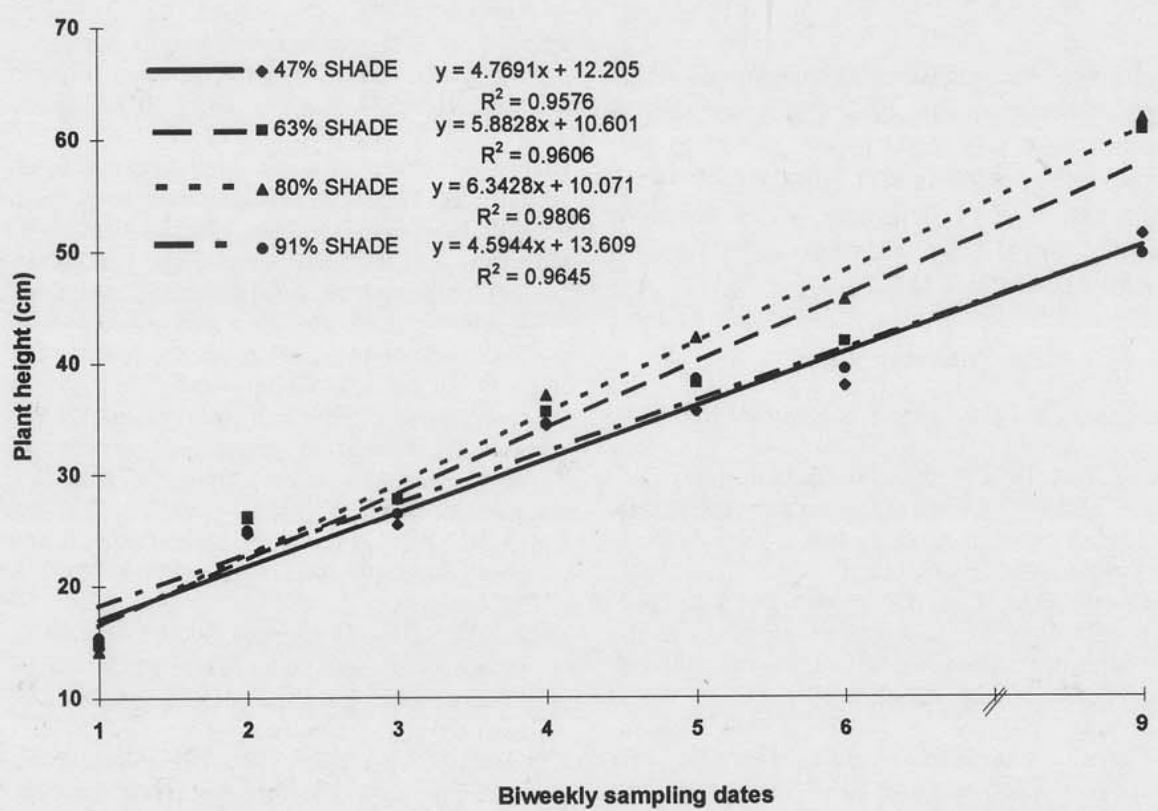

Fig. 2. Plant height of D. sanderana as affected by shade level after 15 weeks of growth. Lines calculated using mean values. to $0 \%$ shade (Murray and Nikols, 1966 ).

Leaf variegation differed in $D$. sanderana plants under the four shade levels (Fig. 3). Other investigators have reported highly variegated plants turned green when exposed to low light levels. Examples were Codiaeum variegatum (L.) Blume (Bequette et al., 1985; Carpenter and Nautiyal, 1969), Ligustrum ovalifolium var. aureum Hassk. (Kunst, 1983; Kunst and Wrischer, 1984), and Fraxinus excelsior var. aurea L. (Wrischer et al., 1986). In contrast, when white leaf area was expressed as percent of total leaf area, leaves of $D$. sanderana grown in the highest shade level $(91 \%)$ had the highest percent white area $(\approx 35 \%)$ (Table 2). Leaves were smaller under $91 \%$ than under $80 \%$ shade, but the white area was larger. Although the difference in total leaf area of plants grown under $47 \%$ vs. $80 \%$ shade was $\approx 7 \mathrm{~cm}^{2}$, the difference in variegated leaf area expressed as a percent of total area was only $\approx 4 \%$. The percent leaf variegation of Peperomia obtusifolia (L.) A. Dietr., also a periclinal GWG chimera, increased as shade levels increased from $27 \%$ to $73 \%$ (Shen and Seeley, 1984). The dissimilarity in the nature of both plants ( $P$. obtusifolia is a dicot and $D$. sanderana, a monocot), and the similarity of light levels in their natural habitats, and their response to increasing shade levels suggest a common response mechanism of periclinal GWG chimeral shade obligate plants to low light levels.

Shading affected internode length and diameter (Table 2). Internode length exhibited a quadratic response and peaked at $80 \%$ shade, then decreased slightly in stems of plants grown under $91 \%$ shade. Thickest internodes developed in plants grown under $47 \%$ shade. Plants grown in shaded habitats develop longer and narrower internodes than their full sun counterparts (Doley, 1978). Conover and Poole (1977) reported significant decreases in trunk caliper of $F$. benjamina L. as shading increased from $0 \%$ to $80 \%$. Similarly, stems of Theobroma cacao L. displayed a curvilinear response to shading (Murray and Nichols, 1966). In the range from $0 \%$ to $75 \%$ shade, the stem diameter was largest under $25 \%$ shade, and smallest under $75 \%$ shade. Our results indicated that a shade obligate plant exhibited a similar decrease in internode diameter as

Table 2. Morphological features of leaves and internodes of $D$. sanderana grown under four shade levels. ${ }^{2}$

\begin{tabular}{|c|c|c|c|c|c|c|c|}
\hline \multirow[b]{2}{*}{ Observation } & \multicolumn{4}{|c|}{ Shade level (\%) } & \multirow{2}{*}{$\begin{array}{c}\text { Significance } \\
P>\mathrm{F}\end{array}$} & \multirow[b]{2}{*}{ Equation } & \multirow[b]{2}{*}{$R^{2}$} \\
\hline & $47 \%$ & $63 \%$ & $80 \%$ & $91 \%$ & & & \\
\hline \multicolumn{8}{|l|}{ Leaf } \\
\hline Fresh mass (g) & 1.2 & 1.2 & 1.4 & 1.1 & 0.03 & $y=-0.09 x^{2}+0.45 x+0.73$ & 0.67 \\
\hline Dry mass (g) & 0.21 & 0.22 & 0.24 & 0.20 & 0.05 & $y=-0.01 x^{2}+0.08 x+0.13$ & 0.84 \\
\hline Specific mass $\left(\mathrm{g} \cdot \mathrm{cm}^{2}\right)$ & 0.032 & 0.031 & 0.031 & 0.030 & NS & NS & \\
\hline Length $(\mathrm{cm})$ & 15.1 & 15.0 & 17.8 & 15.5 & 0.05 & $y=-0.062 x^{2}+0.37 x+2.38$ & 0.63 \\
\hline Width $(\mathrm{cm})$ & 2.7 & 2.8 & 3.0 & 2.8 & 0.05 & $y=-0.53 x^{2}+3.07 x+12.17$ & 0.38 \\
\hline \multicolumn{8}{|l|}{ Leaf area $\left(\mathrm{cm}^{2}\right)$} \\
\hline Total & 35.0 & 36.4 & 41.7 & 38.3 & 0.02 & $y=-1.22 x^{2}+7.63 x+27.91$ & 0.68 \\
\hline White & 8.2 & 8.1 & 11.6 & 12.8 & 0.05 & $y=0.32 x^{2}+0.13 x+7.43$ & 0.90 \\
\hline White $(\% \text { of total })^{y}$ & 21.6 & 21.0 & 25.7 & 34.5 & 0.05 & $y=2.35 x^{2}-7.41 x+26.6$ & 0.99 \\
\hline \multicolumn{8}{|l|}{ Internode } \\
\hline Internode length $(\mathrm{cm})$ & 1.59 & 1.68 & 1.87 & 1.70 & 0.05 & $y=-0.065 x^{2}+0.38 x+1.25$ & 0.74 \\
\hline Internode diameter $(\mathrm{cm})$ & 1.07 & 1.04 & 1.02 & 0.89 & 0.05 & $y=-0.025 x^{2}+0.07 x+1.02$ & 0.96 \\
\hline
\end{tabular}

${ }^{2}$ Values represent means of a combined sample of all individual leaves and internodes developed under experimental conditions.

${ }^{\mathrm{y}}$ Data were subjected to arcsin transformation prior to analysis. 

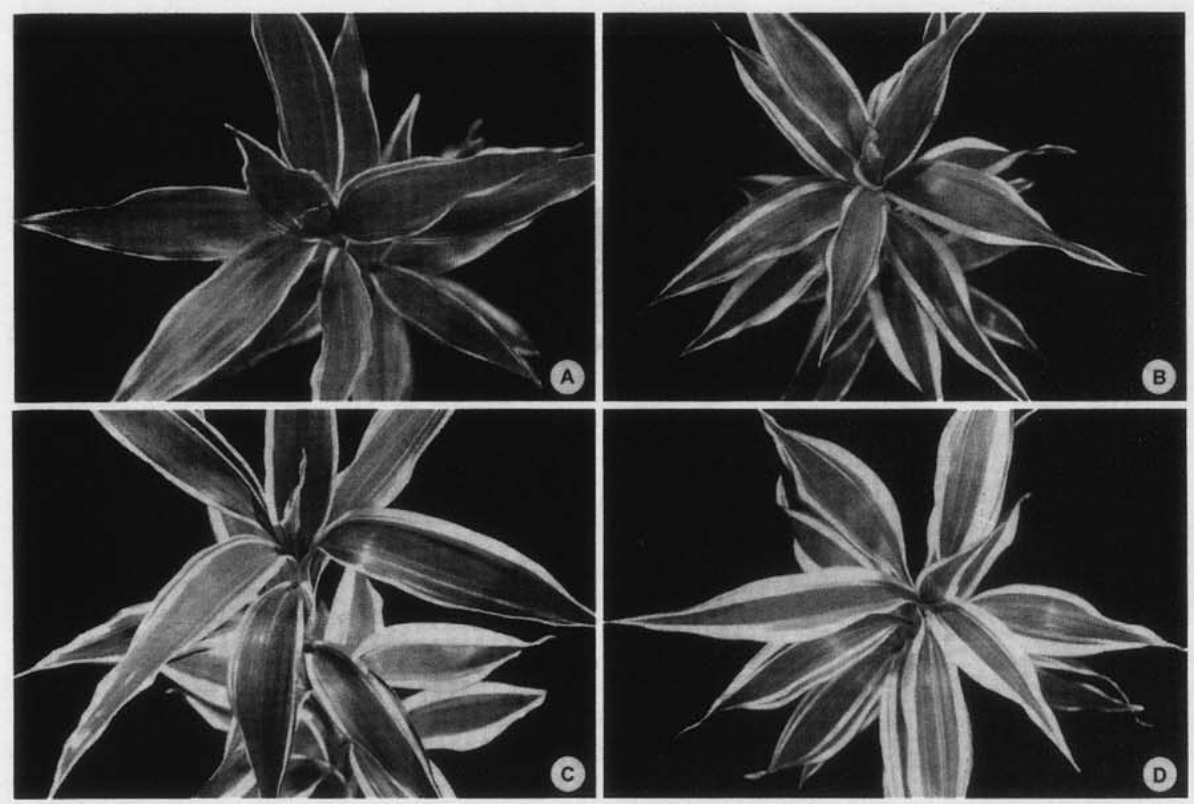

Fig. 3. Leaf variegation of representative plants of $D$. sanderana grown under $47 \%(\mathbf{A}), 63 \%(\mathbf{B}), 80 \%(\mathbf{C})$, and $91 \%$ (D) shade after 15 weeks of growth.

shade levels increased; however, the response was shifted toward higher shade.

The ability of a plant to change its morphology, anatomy, and physiology in response to changes in surrounding environment is termed plasticity. The extent of plasticity varies from one species to another. Preliminary experiments proved that light levels in excess of $30 \%$ shade caused severe growth reduction and death in $D$. sanderana. Based on these results, the light levels used in this study ranged from $47 \%$ to $91 \%$ shade. According to Smith (1982), light levels under dense plant canopies can be reduced to as little as $5 \%$ of the incident light above the canopy. In our experiment, only the last treatment ( $91 \%$ shade) was close to the light intensity of a densely shaded habitat.

Our results indicated that the highest shade level $(91 \%)$ significantly reduced the growth rate of both below and aboveground plant biomass. Plants grown under $91 \%$ shade had shorter stems and fewer leaves than plants grown under $80 \%, 63 \%$, and $47 \%$ shade levels. Plants from $47 \%$ shade were intermediate between plants from $91 \%$ shade and counterparts from $63 \%$ and $80 \%$ shade. As indicated in Table 1 , this was true for all examined morphological features except number of roots, for which $47 \%$ shade plants had the lowest value. In this experiment, apparently the growth rate of $D$. sanderana was optimal under maximum light levels in the range 500 to 1000 $\mu \mathrm{mol} \cdot \mathrm{m}^{-2} \cdot \mathrm{s}^{-1}$ ( $63 \%$ to $80 \%$ ) shade.

In conclusion, for optimal growth rate and marketable variegation, $D$. sanderana 'Ribbon', when grown in shade structures, should be provided with light levels of 500 to 600 $\mu \mathrm{mol} \cdot \mathrm{m}^{-2} \cdot \mathrm{s}^{-1}(80 \%$ shade $)$. However, if $\approx 35 \%$ variegation of the leaf area is desired, light levels should be between 200 to 250 $\mu \mathrm{mol} \cdot \mathrm{m}^{-2} \cdot \mathrm{s}^{-1}(91 \%$ shade $)$.

\section{Literature Cited}

Anderson, T. 1976. Dracaenas. Bul. Fairchild Trop. vol. 5:3-15.

Aung, L.H. 1974. Root-shoot relationships, p. 2961. In: E.W. Carson (ed.). The plant root and its environment. University Press, Virginia Polytechnic Inst., Blacksburg.

Bequette, B.L., T.M. Blessington, and J.A. Price. 1985. Influence of lighting systematics on the interior performance of two croton cultivars. HortScience 20:927-931.

Carpenter, W.J. and J.P. Nautiyal. 1969. Light intensity and air movement effects on leaf temperature and growth of shade requiring greenhouse crops. J. Amer. Soc. Hort. Sci. 94:212-214.

Chase, A.R. and R.T. Poole. 1987. Effect of fertilizer, temperature and light level on growth of Syngonium podophyllum 'White Butterfly'. J. Amer. Soc. Hort. Sci. 112:296-300.

Collard, R.M., J.N. Joiner, C.A. Conover, and D.B McConnell. 1977. Influence of shade and fertilizer on light compensation point of Ficus benjamina. J. Amer. Soc. Hort. Sci. 20:900-902.

Conover, C.A. and R.T. Poole. 1977. Influence of shade and fertilizer source and level on growth quality and foliar content of Philodendron oxycardium Schott. J. Amer. Soc. Hort. Sci. 99:150-152.
Conover, C.A. and R.T. Poole. 1981. Environmental factors, p. 269-283. In: J. Joiner (ed.). Foliage plant production. Prentice-Hall, Englewood Cliffs, N.J.

Doley, D. 1978. Effects of shade on gas exchange and growth in seedlings of Eucalyptus grandis Hillex Maiden. Austral. J. Plant Physiol. 5:723738

Ingram, D.L. 1981. Characterization of temperature fluctuations and woody plant growth in white poly bags and conventional black containers. HortScience 16:762-763.

Ingram, D.L. and D.B. McConnell. 1980. Effect of production shade and fertilization levels on establishment of palms in the landscape. Proc. Fla. State Hort. Soc. 93:72-74.

Kunst, L. 1983. Plastid development in leaves of Ligustrum ovalifolium Hassk. var. aureum at high and low light conditions. Acta Bot. Croat. 42:29-36.

Kunst, L. and M. Wrischer. 1984. Adaptational changes of plastids in the leaves of Ligustrum ovalifolium Hassk. var. aureum at different light levels. Protoplasma 122:132-137.

Murray, D.B. and R. Nikols. 1966. Light, shade and growth in some tropical plants, p. 249-261. In: R. Bainbridge, G.C. Evans, and O. Rackham (eds.). Light as an ecological factor. Blackwell, Oxford.

Poole, R.T., A.R. Chase, and L.S. Osborne. 1991 Dracaena, CFREC - A foliage plant research note. RH-85-D. Inst. Food Agr. Sci., Univ. of Florida, Gainesville.

Rice, S.A. and F.A. Bazzaz. 1989. Growth consequences of plasticity of plant traits in response to light conditions. Oecologia 78:508-512.

Sarracino, J.M.R., M.R. Merritt, and C.K. Chin 1992. Morphological and physiological characteristics of Leea coccinea and Leea rubra in response to light flux. HortScience 27:400-403.

Shen, G.W. and J.G. Seeley. 1984. The effect of shading and nutrient supply on variegation and nutrient content of variegated cultivars of Peperomia obtusifolia. J. Amer. Soc. Hort. Sci. 108:429-433.

Smith, H. 1982. Light quality, photoreception, and plant strategy. Annu. Rev. Plant Physiol. 33:481-518.

Stewart, R.N., and H. Dermen. 1979. Ontogeny in monocotyledonous plants as revealed by studies of the developmental anatomy of periclinal chimeras. Amer. J. Bot. 66:47-48.

U.S. Dept. of Agriculture. 1996. Floriculture crops: 1995 summary. U.S. Dept. Agr., Natl. Agr. Stat. Serv. Sp. Cr. 6-1(96). Washington, D.C.

Vladimirova, S.V., R.A. Bucklin, and D.B. McConnell. 1996. Influence of shade level, wind velocity, and wind direction on interior air temperatures of model shade structures. Trans. ASAE 39:1825-1830.

Whitcomb, C.E. 1979. Growing media, p. 432-459. In: C.E. Whitcomb (ed.). Plant production in containers. Lacebark Publ., Cambridge, Mass.

Wrischer, M., K. Hlousek-Rodojiic, L. Kunst, and N. Ljubesic. 1986. Differentiation of chloroplasts in leaves of aurea plants, p. 685-690. In: G. Akoyunoglou and H. Senger (eds.). Regulation of chloroplast differentiation. Alan R. Liss, New York. 